OLEKSANDR VASYLYEV ${ }^{*}$, MYKOLA BRYCHEVSKYI, IEGOR BRODNIKOVSKYI ${ }^{1}$, MARIUSZ ANDRZEJCZUK ${ }^{2}$, MACIEJ SPYCHALSKI', MAŁGORZATA LEWANDOWSKA ${ }^{2}$, JOSEF MERTENS ${ }^{3}$

${ }^{1}$ Frantcevych Institute for Problems of Materials Science, Kyiv, Ukraine, ${ }^{2}$ Warsaw University of Technology, Materials Science and Engineering Dept., Warsaw, Poland, ${ }^{3}$ Forschungszentrum Jülich $\mathrm{GmbH}$, Institute of Energy and Climate Research, Germany
Scientific paper

ISSN 0351-9465, E-ISSN 2466-2585

UDC: 669.295 .058

doi:10.5937/ZasMat1602244V

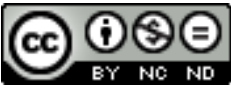

Zastita Materijala 57 (2)

$244-252(2016)$

\title{
EB-PVD helium-tight zirconia ceramic coating on porous ceramic substrate
}

\begin{abstract}
The dense helium impermeable zirconia coating deposited on highly porous $\mathrm{NiO}-\mathrm{ZrO}_{2}$ substrate with EB-PVD were studied with transmission and scanning electron microscopy. The plausible condensation mechanisms of zirconia from its vapour phase onto zirconia and nickel oxide phases of the substrate were established. The condensation of zirconia was identified as a two-stage process with two mechanisms of growth, planar and cellular, similar to solidification from the liquid phase. $\mathrm{ZrO}_{2}$ condensation on $\mathrm{ZrO}_{2}$ and NiO phases occurs with different routes. During the planar growth on the $\mathrm{ZrO}_{2}$, the $\mathrm{ZrO}_{2}$ film nucleates and grows up to $\sim 0.3-0.5 \mu \mathrm{m}$ with no orientation preference as continuous "layer by layer" defective film. The planar $\mathrm{ZrO}_{2}$ film on the NiO of $\sim 0.5$ $0.7 \mu \mathrm{m}$ thickness is discontinuous and porous; it consists of oriented structurally perfect "islands". The differences found are probably the result of differences in the melting temperature of $\mathrm{ZrO}_{2}$ and $\mathrm{NiO}$, and $\mathrm{Zr}$ and $\mathrm{Ni}$ affinities to oxygen as well as their different behavior under high vacuum. The deposition affected zone surrounding the $\mathrm{ZrO}_{2}$ nucleation site is established.
\end{abstract}

Keywords: Zirconia Ceramic Coating; Helium Gas-Tightness; Nucleation Mechanism; Growth Mechanism; Thin Structure; Electron Beam - Physical Vapor Deposition.

\section{INTRODUCTION}

The task of deposition of a dense gas-tight coating on porous substrate does arise at production of different protective coatings and thin electrolytes in solid oxide fuel cells (SOFCs). The very idea of a dense and helium-gas tight coating to be deposited on highly porous ( $>30 \%$ ) substrate with electron beam - physical vapor deposition (EB-PVD) technique looks as unbelievable and impossible.

Indeed, the observed structures of zirconia coatings allow a gas impermeability doubt about EB-PVD coatings, especially those that are deposited on rough porous substrates. The reasons of insufficient gas-tightness are rooted in coating nucleation and growth.

${ }^{*}$ Corresponding author: Oleksandr Vasylyev

E-mail: vasylyev@ipms.kiev.ua

Paper received: 28. 01. 2016.

Paper accepted: 04. 03. 2016.

Paper is available on the website: www.idk.org.rs/journal
The available literature deals mainly with the nucleation and the growth of films deposited on perfect dense substrates. A few models (VolmerWeber - "island" or 3-D nucleation; Frank-Van der Merwe - ideal epitaxy or "layer by layer"; and mixed model by Stranski-Krastanov, SK Growth) of epitaxial film growth [1,2] and four stage microstructural evolution (nucleation, islanding, channel filling, and continuous film growth) based on structural studies of film surfaces at different stages of their growth are well developed [2,3], as well as many theoretical models of these processes. As to the structure of thick films, thermal barrier coatings (TBCs) mainly, models developed or their combinations [4,5] are usually accepted.

Historically, the EB-PVD has been widely used to fabricate ceramic TBCs. Now, this method is well-developed. The major advantage of this technique in the case of SOFC electrolyte deposition is production of continuous zirconia layer on highly porous substrate like $\mathrm{NiO}-\mathrm{ZrO}_{2}$ anode composite. Electrolyte film must be impermeable for gases (fuel and air) that is as the 
main prerequisite ensuring reliable SOFC operation.

EB-PVD is a promising process that might enhance the electrochemical performance of SOFCs. EB-PVD deposited thin layers contribute to the SOFC lifetime increase and their cost reduction. It was found that SOFC based on electrolyte made of $1 \mathrm{Ce} 10 \mathrm{ScSZ}$ zirconia, cubic structure of which is stabilized with $10-\mathrm{mol}$. \% $\mathrm{Sc}_{2} \mathrm{O}_{3}$ and 1-mol. \% $\mathrm{CeO}_{2}$, deposited by EB-PVD have demonstrated an area specific resistance of $0.6 \mathrm{ohm} \cdot \mathrm{cm}^{2}$ at $600{ }^{\circ} \mathrm{C}$ and a He leakage rate below $10^{-4} \mathrm{mbar} \cdot 1 \cdot \mathrm{cm}^{-2} \cdot \mathrm{s}^{-1}$ [6]. The conductivity of EB-PVD deposited films on a NiO-8YSZ anode is $\sim 50 \%$ higher than that of layers made with traditional SOFC technology [7].

For a long time, however, this technique could not meet high SOFC requirements as to the gas leakage after $\mathrm{NiO}-\mathrm{ZrO}_{2}$ reduction and transformation of $\mathrm{NiO}-\mathrm{ZrO}_{2}$ ceramic composite into its $\mathrm{Ni}$ $\mathrm{ZrO}_{2}$ cermet. The fast electron beam evaporation and subsequent vapor phase condensation on the substrate result in creation of structure heterogeneity and porosity that may affect coating properties. Porosity had an influence on electrical conductivity and gas-tightness $[8,9]$.

The reasons of such the dual contradictive behavior of EB-PVD coatings was unclear and have required an additional research.

In present work, structure of very perspective Ceria doped Scandia Stabilized Zirconia (1Ce10ScSZ) electrolyte film deposited on highly porous $(>30 \%)$ substrate by EB-PVD technique has been studied. The purpose of the study was to examine the structural features in the zone of the transition from the porous NiO-8YSZ substrate to the dense EB-PVD 1Ce10ScSZ film, or the zone of the anode-electrolyte interface (AEI), in order to establish the nucleation and growth mechanisms and structural features of electrolyte films formed at EB-PVD.

\section{EXPERIMENTAL}

The 1-mol. \% $\mathrm{CeO}_{2}-10$-mol. \% $\mathrm{Sc}_{2} \mathrm{O}_{3}-\mathrm{ZrO}_{2}$ co-deposited powder used in the experiments described here was developed by Prof. Victor Vereshchak and produced at Vil'nohirs'k Mining \& Metallurgical Plant, Ukraine. The doping of the zirconia with $\sim 0.5$ wt. \% $\mathrm{SiO}_{2}$ and $\sim 0.025$-wt. \% $\mathrm{Al}_{2} \mathrm{O}_{3}$, as well as the nano size $(10-20 \mathrm{~nm})$ of the initial particles are chemical and structural features of the powder, which insures high electrical conductivity at its SOFC electrolyte application [10].

Porous $(20-25 \%) \quad 1 \mathrm{Ce} 10 \mathrm{ScSZ}$ cylindrical powder compacts of $\varnothing 12-15 \mathrm{~mm}$ and $10-15 \mathrm{~mm}$ height were prepared with uniaxial pressing and subsequent sintering at $1200-1300{ }^{\circ} \mathrm{C}$ for 1 hour in air and then used as ingots in the EB-PVD process. For deposition, the VU-2M installation (Smorgon, Belarus) operating under hydrocarbon free vacuum $\left(10^{-5} \mathrm{~Pa}\right)$ was used.

1Ce10ScSZ electrolyte films of 9,20 and 65 $\mu \mathrm{m}$ thicknesses were deposited. The substrate temperature during the deposition process was either 700 or $900{ }^{\circ} \mathrm{C}$. Samples were annealed for 1.5 hour in air at temperatures in range of 700 to $1200{ }^{\circ} \mathrm{C}$.

Thick ( 1 to $1.5 \mathrm{~mm}$ ) porous NiO-8YSZ pellets containing $\sim 30 \mu \mathrm{m}$ dense electrochemically active $\mathrm{NiO}-8 \mathrm{YSZ}$ anode layer were used as substrates. It could be reasonable to assume that during cooling after the EB-PVD process of applying the electrolyte film a mechanical stress develops in the plane of the AEI due to differences in thermal expansion of electrolyte layer and substrate. This stress might lead to delamination of the electrolyte film from the support. In fact, in-plane stresses are larger for thin films, however, since the fracture is a result of the elastically stored energy; thicker films are more prone to fail due to delamination. The available results suggest an optimum film thickness of $\sim 10 \mu \mathrm{m}$, which is chosen mainly based on electrochemical requirements along with the need to obtain a gas-tight film.

The crystalline structure was studied with X-ray diffraction (XRD) using DRON, Burevestnik, RF

The structural characterization of the samples was carried out on cross-sections with scanning electron microscopes (SEM, Carl Zeiss CMI SEM LEO 460 and Hitachi SU-70, 2-10 kV). More localized structural investigations were based on scanning transmission electron microscope (STEM, Hitachi HD-2700, $200 \mathrm{kV}$ ). The thin foils for STEM investigations were prepared using the Focused Ion Beam (FIB, Hitachi FB 2100) technique.

Gas leakage of $60 \times 60 \mathrm{~mm}^{2}$ fuel cells was tested with the single cell test facility at Jülich Research Center, Germany, according to their standard testing procedure using helium gas.

\section{RESULTS AND DISCUSSION}

\subsection{Structure revealed at a micron level}

A polished cross-section of the transitional zone between the electrolyte film and its $\mathrm{NiO}-\mathrm{ZrO}_{2}$ substrate (AEI zone) shows that the EB-PVD film has a directional and laminar structure (Fig. 1).

It is seen that the substrate is well covered by zirconia film in spite of its rather big pores. With respect to structural features, columns and filaments, nano- and microlaminae, cracks between filaments and groups thereof and pores can be discerned. The interface line is discontinuous; it is interrupted by pores as it is seen in areas 
highlighted by the white ellipses. Some less structured layer with a lighter color can be distinguished also in the electrolyte zone nearest to the anode.

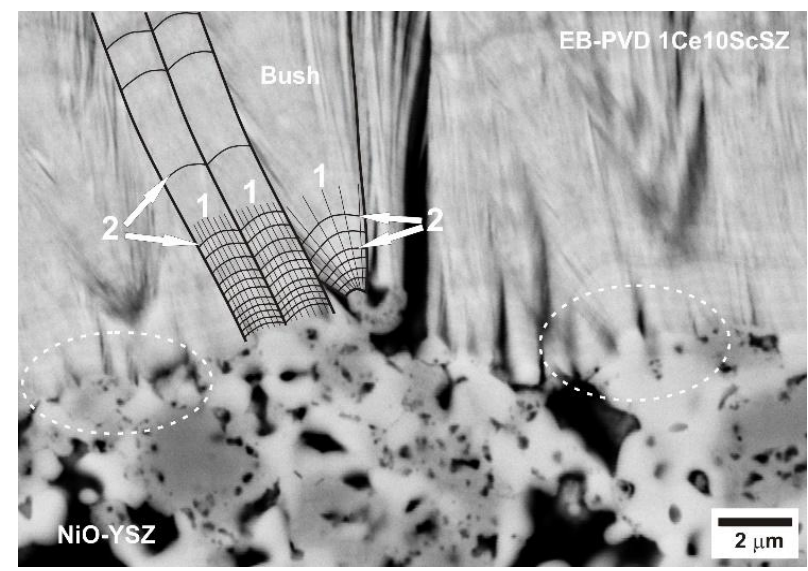

Figure 1 - SEM image of polished cross-section of the anode - electrolyte interface zone obtained with backscattered electrons. In the anode part, white areas are $\mathrm{ZrO}_{2}$ (1Ce10ScSZ) phase; light grey ones are NiO phase; black areas are pores. In the electrolyte part, filaments (1), bushes of filaments and nano- and microlaminae (2) are clearly recognized. Black areas are interfilament cracks and pores. A lighter stripe bordering the NiO-

1 Ce10ScSZ composite can be clearly discerned. Ellipses highlight areas with interface discontinuities resulting from the nucleation in groupings of cell/filaments (bushes) [11].

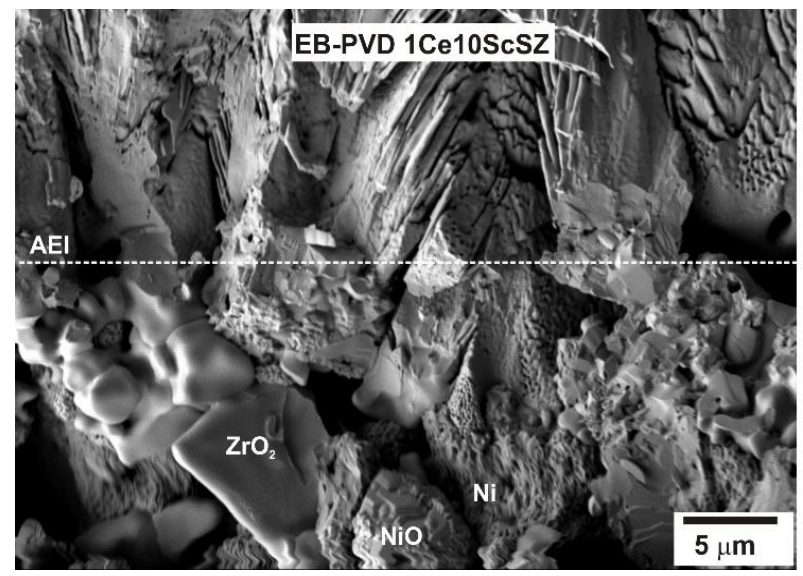

Figure 2 - SEM image of the anode-electrolyte interface zone revealed in a fracture cross-section of the NiO-8YSZ anode substrate-1Ce10ScSZ $E B-P V D$ electrolyte film obtained with secondary electrons [11].

Fig. 2 displays the SEM image of a fracture cross-section of the $\sim 65 \mu \mathrm{m}$ thick film that has been fractured in a bi-axial bending test. As it is seen, the electrolyte film has a well-defined columnar nano-structure and has failed at the transcolumnar cleavage with some intercolumnar fracture that implies rather high adhesion between the columns. It is remarkable, that the transition from porous to visibly non-porous state occurs at a film thickness of 2 to $3 \mu \mathrm{m}$.

It is seen that the substrate is well covered by zirconia film in spite of its rather big pores. With respect to structural features, columns and filaments, nano- and microlaminae, cracks between filaments and groups thereof and pores can be discerned. The interface line is discontinuous; it is interrupted by pores as it is seen in areas highlighted by the white ellipses. Some less structured layer with a lighter color can be distinguished also in the electrolyte zone nearest to the anode.

Fig. 2 displays the SEM image of a fracture cross-section of the $\sim 65 \mu \mathrm{m}$ thick film that has been fractured in a bi-axial bending test. As it is seen, the electrolyte film has a well-defined columnar nano-structure and has failed at the transcolumnar cleavage with some intercolumnar fracture that implies rather high adhesion between the columns. It is remarkable, that the transition from porous to visibly non-porous state occurs at a film thickness of 2 to $3 \mu \mathrm{m}$.

It can also be seen that the porous structure of the anode is well covered by the electrolyte layer. There are no visible delamination cracks along the interface between the film and its $\mathrm{NiO}-8 \mathrm{YSZ}$ substrate that might eventually lead to SOFC failure. The EB-PVD film has no visible porosity. It can be seen also that the EB-PVD electrolyte film on the porous NiO-8YSZ substrate grows like bushes consisting of long branches, which have nano-sized diameter.

\subsection{Structure revealed at a submicron level}

The structure of the AEI area of the 1 Ce10ScSZ film formed on 8YSZ grains of the anode $\left(\mathrm{ZrO}_{2}-\mathrm{ZrO}_{2} \mathrm{AEI}\right)$ after annealing at $1100{ }^{\circ} \mathrm{C}$ is shown in Figs $3 \mathrm{a}-3 \mathrm{c}$. It is seen that zirconia grain of the substrate is covered by a continuous, smooth, porous layer of $300-500 \mathrm{~nm}$ thickness, which has no any other visible structure. This layer is covered by columns or filaments those are almost perpendicular to the AEI along all the visible ( 7-8 $\mu \mathrm{m})$ part. For more expression, the deposited columns / filaments surround the supporting $8 Y S Z$ grain like petals of daisy or sunflower.

The porosity of the $1 \mathrm{Ce} 10 \mathrm{ScSZ}$ layer is high and has no any visible order. The size of pores displays a large scatter of values in the 10-60 nm range. 

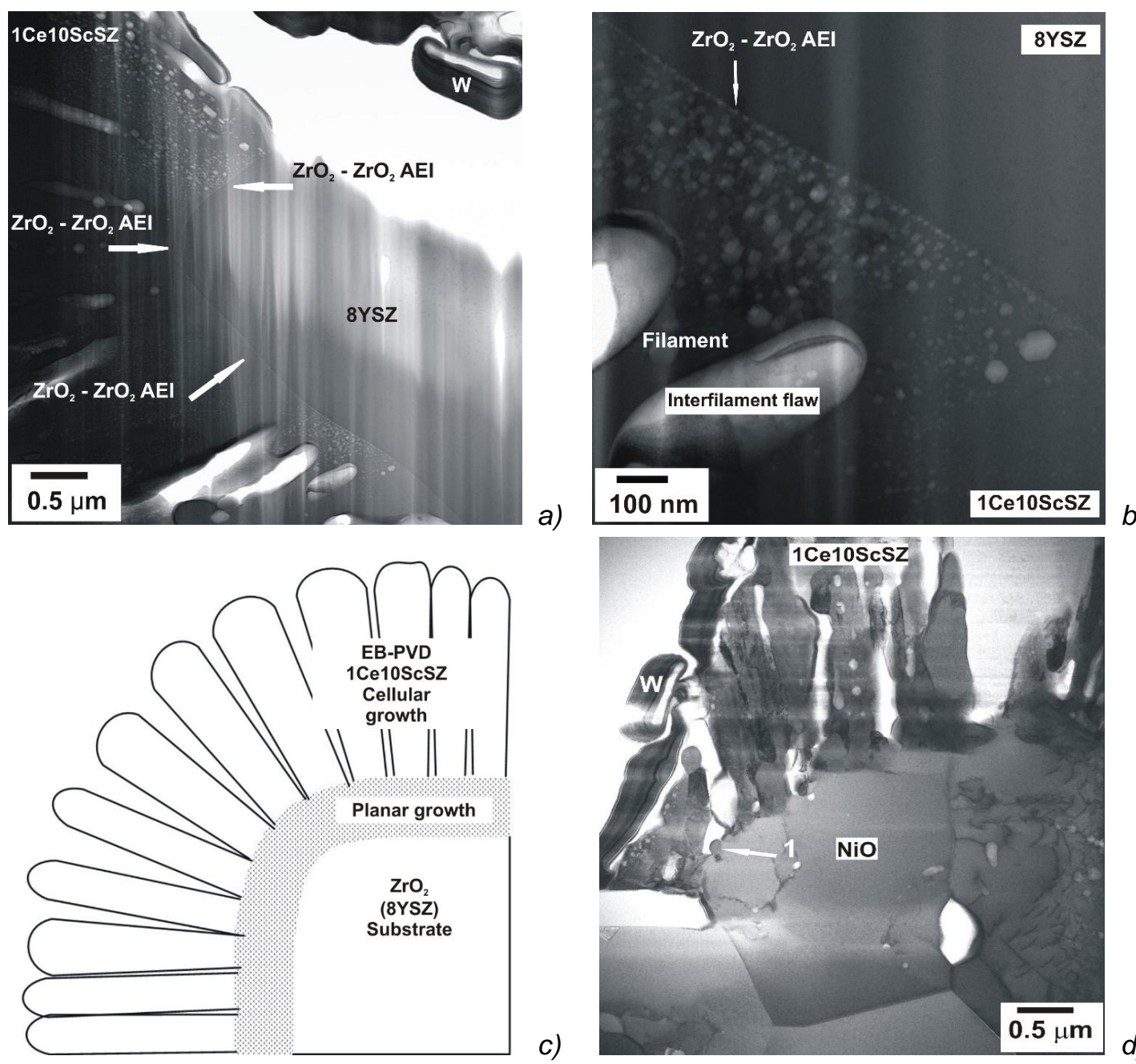

a)
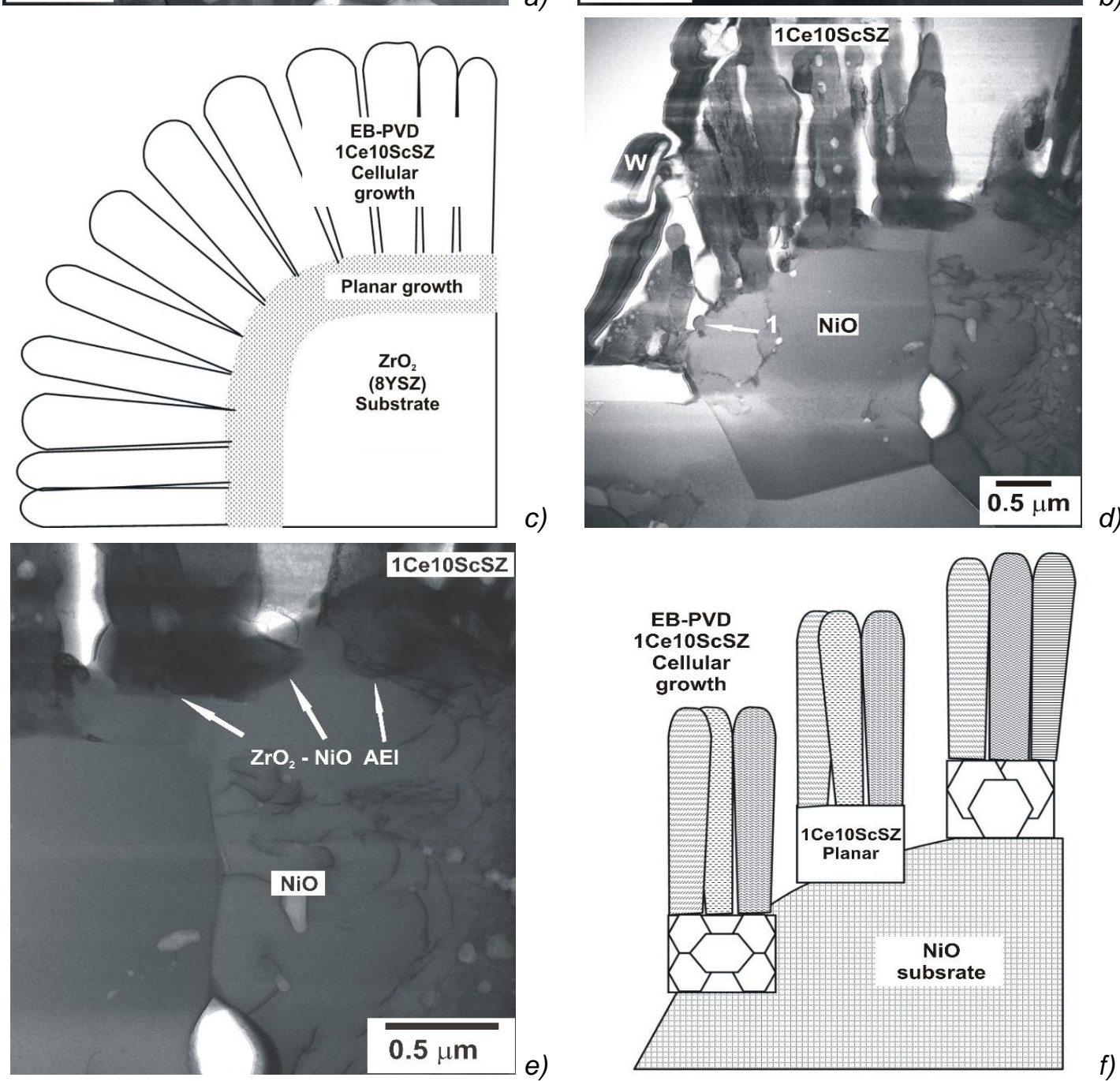

d)

Figure 3 - STEM micrographs of a zone around the anode - electrolyte interface between 1Ce10ScSZ electrolyte film deposited on $8 \mathrm{YSZ}(a, b)$ and $\mathrm{NiO}(d, e)$ grains of the porous $\mathrm{NiO}-\mathrm{ZrO}_{2}$ anode composite with $E B-P V D$ in the state after annealing at $1100{ }^{\circ} \mathrm{C}$ taken at two magnifications, and schematical reconstructions of the 1 CE10SCSZ structures observed on the $8 Y S Z$ (c) and the NiO (f) substrates. W-protecting W film, 1 rudimentary 1 Ce10ScSZ EB-PVD nucleus [11]

The line of the 1Ce10ScSZ - 8YSZ AEI looks smoothly curved; it consists of an uniform chain of pores of around $10 \mathrm{~nm}$ size, which makes the AEI easy visible. It is possible to assume that the 
electrolyte layer was amorphous and very defective initially and the facetted pores in the layer have arisen during annealing (Fig. 3b).

The investigated columns / filaments had about 100 to $300 \mathrm{~nm}$ diameters. They were separated by discontinuous, longitudinal interfilament flaws of 100-200 nm width and a few $\mu \mathrm{m}$ lengths.

Schematically, the structure of $1 \mathrm{Ce} 10 \mathrm{ScSZ}$ film on the 8YSZ substrate deposited with EB-PVD described above is sketched in Fig. 3c.

With respect to the $1 \mathrm{Ce} 10 \mathrm{ScSZ}-\mathrm{NiO}$ part of the $\mathrm{AEI}$, the structural features are somewhat more complicated as it is seen in Figs $3 d-3 f$. In contrast to the $1 \mathrm{Ce} 10 \mathrm{ScSZ}-8 \mathrm{YSZ} \mathrm{AEI}$, the $1 \mathrm{Ce} 10 \mathrm{ScSZ}$ $\mathrm{NiO}$ AEI is not smooth. Moreover, it is discountinuous and stepped. Its discrete parts or island are dense, monocrystalline or polycrystalline (Figs 3d, 3e).

Fig.3d displays a few zirconia (1Ce10ScSZ) dendrites, or bushes of columns / filaments, which have nucleated on a NiO grain along $\sim 3.5 \mu \mathrm{m}$ of its boundary length. In contrast to the $1 \mathrm{Ce} 10 \mathrm{ScSZ}$ $8 Y S Z$ AEI, the zirconia dendrites have nucleated here on some preferable crystallographic planes like trees on a hill terrace. Zirconia dendrites seem to nucleate and grow on the NiO substrate in one direction, probably [100]. In full analogy with bushes or trees, a trunk, branches / filaments, and even some $1 \mathrm{Ce} 10 \mathrm{ScSZ}$ root in the $\mathrm{NiO}$ substrate may be distinguished. Moreover, the zirconia trunks seem to root into the $\mathrm{NiO}$ grain (Fig. 3e). The nucleation on preferable crystallographic planes makes the 1Ce10ScSZ - NiO AEI line as discontinuous and terraced. The area bordering to the $\mathrm{AEI}$ on the $\mathrm{NiO}$ side has a different contrast than the rest of the NiO grain, and contains a few dislocations. The thickness of this area is around $0.5 \mu \mathrm{m}$. It might be stated that the $1 \mathrm{Ce} 10 \mathrm{ScSZ}$-tree was rooting into the modified part of the $\mathrm{NiO}$ grain. Some 1Ce10ScSZ-trunks look as monocrystalline; other trunks are polycrystalline, containing wellvisible facetted grains of $\sim 100-300 \mathrm{~nm}$ size. Pores between trunks along the line of their $\mathrm{AEI}$ as well as other pores and cracks located between trunks and their upper branch / filaments are observed. Some underdeveloped nucleus is observed also on the surface of the $\mathrm{NiO}$ grain inside the large pore between two $1 \mathrm{Ce} 10 \mathrm{ScSZ}$ trunks. The height of trunks to their branching site is roughly around 0.5$0.7 \mu \mathrm{m}$. It is interesting that similar to usual trees, the trunks of $\mathrm{ZrO}_{2}$-trees have also some well-visible thickening near the $\mathrm{NiO}$ "ground", i.e. at their very base.

Schematically, the processes of nucleation and growth of $\mathrm{ZrO}_{2}$ film on the NiO substrate at the EBPVD process are sketched in Fig. 3f.

The presented data clearly show that vapors of the 1Ce10ScSZ compound (later - just as "zirconia" that also is meaning "cubic zirconia") produced with electron beam evaporation in a EBPVD process condense on the two solid phases of the three phase substrate (two solid phases are $8 \mathrm{YSZ}$ and $\mathrm{NiO}$, the third one is pores) with two different mechanisms of the film nucleation and growth. By other words, zirconia is depositing and condensing on zirconium and nickel oxides in very different ways.

With respect to the condensation of zirconia on zirconia heated to $700-900{ }^{\circ} \mathrm{C}$ (that is around 0.3 to 0.4 of $\mathrm{ZrO}_{2}$ melting temperature in absolute temperatures) the following conclusions could be drawn.

Initially, the zirconia condenses on the smooth surface of zirconia grains presumably in terms of the Frank - Van der Merwe's "layer by layer" model. It might be assumed that these layers are amorphous and have defects, i.e., the deposition of a first zirconia portion occurs as the "amorphous layer on an amorphous substrate" model. During annealing this amorphous defective layer crystallizes and pores are formed (Fig. 3b). The chain of these pores makes the 1Ce10ScSZ - 8YSZ AEI well visible. Pores are observed across the band of 0.3 to $0.5 \mu \mathrm{m}$ thickness where no other structural features are visible by TEM. Moreover, there is no visible order in the pore arrangement that could indicate any 3D-island growth. The porous band appears to be non-coherent defective material that is not densified fully even during heat treatment at $1100{ }^{\circ} \mathrm{C}$. In spite of the non-ideal structure of this porous band, it is followed by cells/filaments, which can be seen as evidence that the mechanism of film growth was planar and it might be termed as "defective layer by defective layer".

In terms of the condensation developed for solidification of the liquid phase, the planar growth is realized as perfectly pure material, whose purity is ensured by pushing outwards any alloying elements or impurities at the front of the solid-liquid interface (i.e. the phenomenon of zone refinement [12].

The solid-liquid interface moves as a planar surface in a direction opposite to the direction of heat removal pushing impurities ahead its front where they are accumulated afterwards. Eventually, their segregated amount may become critical, i.e. enough for the so-called constitutional supercooling that means literally that the thermal supercooling is reached locally for the portion of liquid, which is enriched by the segregating elements in comparison with the pure liquid.

As result, the growth mechanism will be changed. A few new cells / branches / filaments will be nucleated at the solidification front, which will jump ahead due to quick solidification of the enriched liquid portion. The latent heat of fusion will be released at this moment that will result in some stop of the solidification front and redistribution of a new portion of impurities. The planar growth will be 
replaced by the cellular one since new nuclei will be created and conditions for solidification are changed chemically, or constitutionally. A superposition of at least three physical phenomena namely the thermal supercooling, the fusion latent heat release and the constitutional supercooling occur. It results in structural and chemical heterogeneity, or laminarity, which is well-visible at the micro level in single crystals, metallic welds [13] and EB-PVD films as we could observe here (Fig. 1). As an aside, it is generally accepted that some technical instabilities are reasons for the laminar growth.

In full analogy with the solidification of the liquid phase, with the condensation of $\mathrm{ZrO}_{2}$ on a monocrystalline zirconia substrate (locally, within one $\mathrm{ZrO}_{2}$ grain of porous $\mathrm{NiO}-\mathrm{ZrO}_{2}$ composite) heated up to $700-900{ }^{\circ} \mathrm{C}$, we indeed see that zirconia initially condenses according to a planar mechanism and the material grows by "layer by layer" up to about $0.5 \mu \mathrm{m}$ thickness. The only visible structural feature of the material condensed during this stage is nanosized porosity that is revealed after annealing.

It means that the conditions, which are able to change the EB-PVD film growth mechanism, are reached at the $\sim 0.5 \mu \mathrm{m}$ film thickness. The planar mechanism is replaced by a cellular one. New nuclei are visible. These nuclei transform into cells, which may grow, in our case, as long filaments across all the film thickness. They were nucleated like islands but not on the original $\mathrm{ZrO}_{2}$ substrate (zirconia grain) but the new zirconia film formed by the planar mechanism on the original zirconia substrate.

Beginning from this point, filaments grow in competition with their neighbors as branches of dendrites. The fact that filaments form as dendrite branches is seen in the flaws between the large bushes of filaments, tips of which have short secondary branches [11].

It was observed also [11] that in planes of cleavage, broken filaments have spherical nodules on their tips, i.e. they look like "heads of matches" instead of being facetted that might be at a brittle fracture of zirconia. If this phenomenon could be observed on free surface like in an interbush flaw, these heads could evidence filament growth cessation, accumulation of admixtures, latent heat release and tip melting. But the "match heads" are observed in a dense bush body. In this case, fritted appearance of a broken filament tip may evidence a release of energy localized in nano-sized filament due to limited heat dissipation at its deformation before fracture similar to observed spheroids in metallic glasses [14].

In the course of their growth, the filaments create their own condensation laminarity, a collective picture of which is clearly seen on the polished cross-sections of bulk samples (Fig. 1).
The filaments bend to the vapor flow in order to grow like plants, which bend and turn to the sunlight in order to ensure their growth. As the filament is growing, conditions favoring supercooling may arise again; as a result, secondary filaments will nucleate on the tips of the primary ones.

So, the moment when the filament bush can be formed is approaching. Nevertheless, it has to be kept in mind, that in the very beginning, the cellfilaments arise perpendicularly to the substrate surface, which may result in the formation of a 'fan' around the substrate $\mathrm{ZrO}_{2}$ grain as can be seen in Fig. 3a and sketched in Fig. 3c.

The high nano-porosity formed at the stage of planar growth of the $\mathrm{ZrO}_{2}$ layer on the $\mathrm{ZrO}_{2}$ substrate and observed in samples annealed at $1100{ }^{\circ} \mathrm{C}$ (Fig. 3b) cannot yet be explained consistently. This porosity might indicate the low density of the initial portions of condensed zirconia in high vacuum that act as reducing agent. The evidence of this may be the well-known fact that as-deposited zirconia coatings look grey, which is always interpreted as a result of an oxygen deficiency. Annealing in air eliminates this deficit; the zirconia film becomes transparent and shines brilliantly. As it can be seen in the TEM, though, this procedure is not able to densify zirconia produced at this stage. The initially deposited zirconia is loose and probably amorphous. It has a lot of crystallographic defects, which may promote oxygen ionic conductivity. The reasons for this condensation behavior could be the comparatively low temperature of the substrate and, as a result, a high condensation rate. However, the circumstance that a vaporized zirconia deposits on the zirconia substrate, which has some oxygen deficit due to the deep vacuum conditions (we used $\sim 10^{-5} \mathrm{~Pa}$ vacuum free of hydrocarbons) and temperature of $700{ }^{\circ} \mathrm{C}$, is sufficient for the deposited zirconia to lose oxygen. Annealing just recrystallizes pores and makes them visible (defect annealing). Indeed, we see that annealed nanosized pores are wellfacetted (Fig. 3b).

In the case of heterogeneous condensation of zirconia on the nickel oxide substrate, some different microstructural features can be seen, although the main conclusions on the growth of zirconia films with two (planar and cellular) mechanisms are confirmed here also.

The first distinction is that there is no initial continuous $\mathrm{ZrO}_{2}$ film that could grow with the planar mechanism along the whole surface of the $\mathrm{NiO}$ grain (Figs 3d, 3e) as it is observed at the $\mathrm{ZrO}_{2}$ - $\mathrm{ZrO}_{2}$ deposition (Figs $3 \mathrm{a}-3 \mathrm{c}$ ). Instead of "one" wide nucleus where the whole zirconia grain serves as the nucleus and zirconia condensates by "layer by layer" at the stage of the planar mechanism, a number of much smaller nuclei can be detected, more than a dozen in our case. It is possible to assume that these nuclei were initiated as "islands" 
but instead of lateral spreading in order to occupy the entire $\mathrm{NiO}$ grain surface, they grow in height. As a result, several separate crystals have been nucleated and grown on each $\mathrm{NiO}$ grain.

The second distinction is that the initial part of $\mathrm{ZrO}_{2}$ film grown on the $\mathrm{NiO}$ substrate by the planar mechanism has no any visible pores even after annealing (Figs $3 \mathrm{~d}, 3 \mathrm{e}$ ). As a result, the $\mathrm{ZrO}_{2}-\mathrm{NiO}$ $\mathrm{AEI}$ is hardly visible in comparison with the $\mathrm{ZrO}_{2}-$ $\mathrm{ZrO}_{2} \mathrm{AEI}$.

Considering these features, the only might be concluded that these zirconia crystals are bushes of filaments, which have grown with two mechanisms also - planar and cellular growth. The very short trunk of the bush grows as the planar structure, and the branching filaments grow with the cellular mechanism. As result, no continuous band of planar growth exists. Instead of a band, islands of planar growth covered by a few cell / filaments are observed (Figs $3 d-3 f$ ). The cells / filaments nucleate as a result of the constitutional supercooling in the frame of each planar island, thus, appearing as trunks of bushes. However, the islands do not spread along the entire $\mathrm{NiO}$ grain surface in order to occupy it completely. They had no enough material and time.

Talking about the sites of nucleation and orientation of the $\mathrm{ZrO}_{2}$ bushes on $\mathrm{NiO}$ substrates, we may say that they are sited on the curved surface of the $\mathrm{NiO}$ grain as terrace (Figs 3 and 4). They cover all the curved grain surface like trees on terraces of a steep hill, i.e. all the bushes have grown in one direction, likely [100], and on the same crystallographic planes, probably the $\{100\}$ family.

For more expression using the botany terminology, we might say that the $\mathrm{ZrO}_{2}$ bush, which has grown on the $\mathrm{NiO}$ substrate has its "shoot and root systems" as a reconstruction shows in Fig. 4. Its "shoot system" consists of a short $(\sim 0.3$ to $0.7 \mu \mathrm{m})$ trunk like in shrub plants (1), on which a few branches (2) in form of filaments have nucleated and grown. As to the structure of the crown, it can be stated that it may be both monocrystalline (1) and polycrystalline (crowns in the central part of the picture). In the grains of polycrystalline zirconia trunks, structural domains are observed. Looking at how our 'bush' is joined to the ground, we see some "root system" according to the botany terminology. Moreover, near the interface surface, the trunk has some bulge like a nodule on the tree trunk near its root. The bush's "root" is probably "hidden" in some zone (3) surrounding the site of joining of the $\mathrm{ZrO}_{2}$ trunk with the $\mathrm{NiO}$ substrate that has some contrast gradient. The NiO twin area may be discerned (4).

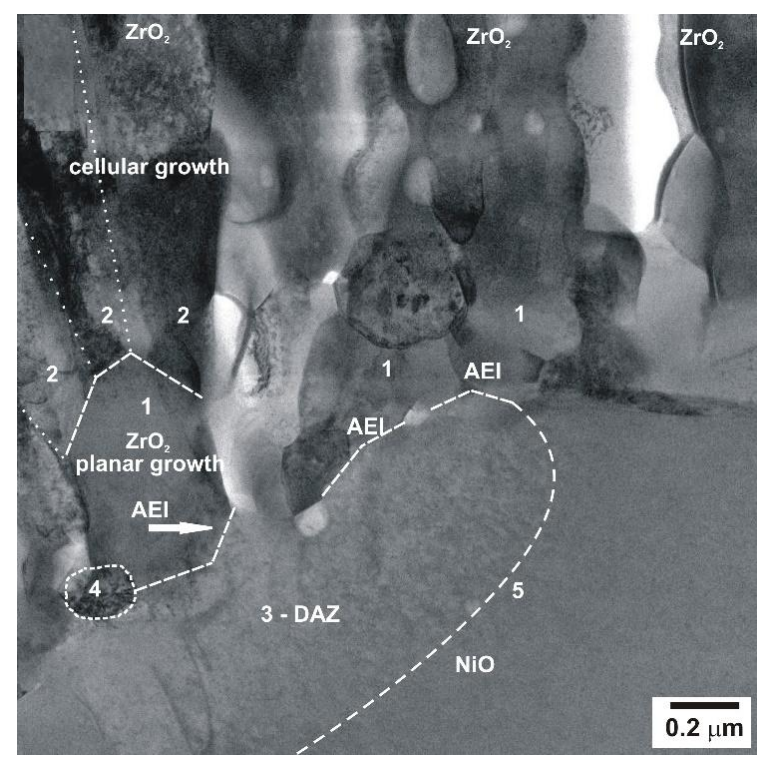

Figure 4 - Schematic reconstruction of $\mathrm{ZrO}_{2}$ bush nucleation and growth on a NiO grain. The $\mathrm{ZrO}_{2}$ bush consists of a short trunk (1) grown in the course of planar growth and followed by a few branches (2) grown with the cellular mechanism as laminated cells/filaments. The laminarity results from the constitutional supercooling and technical instabilities occurring during their growth. The bush is sited on its deposition affected zone (3) of the NiO substrate and is separated from it by the hardly visible anodeelectrolyte interface (4) is the NiO twin (5) is an imaginary boundary of the deposition affected zone stripe in the NiO substrate grain [11].

Hence, one more analogy with condensation of a melt was found too.

The zone, surrounding the $\mathrm{ZrO}_{2}$ bush base (band 3 in Fig. 4), as a matter of fact, might be called as some "deposition affected zone (DAZ)" in full analogy with the "heat affected zone" (HAZ) that is widely used in a structural description of metallic welds. The HAZ is characterized by a typical structure of metal subjected to heat treatment by melted metal. As we can see, the similar situation exists during the deposition of $\mathrm{ZrO}_{2}$ vapor on $\mathrm{NiO}$ where the DAZ may be identified. The $\mathrm{NiO}$ zone adjacent to the crown of the $\mathrm{ZrO}_{2}$ bush has a structure that looks different from the rest of the $\mathrm{NiO}$ grain (Figs 3 and 4). This conclusion is confirmed additionally by the way of joining $\mathrm{ZrO}_{2}$ with $\mathrm{NiO}$. In the $\mathrm{ZrO}_{2}-\mathrm{ZrO}_{2}$ case, $\mathrm{ZrO}_{2}$ is placed on $\mathrm{ZrO}_{2}$ with no any indications of a strong interaction. Both the first layers of $\mathrm{ZrO}_{2}$ in planar growth and following $\mathrm{ZrO}_{2}$ cells / filaments of the cellular growth grow independently on orientation of the $\mathrm{ZrO}_{2}$ substrate. As a result, a fan of $\mathrm{ZrO}_{2}$ filaments is created (Figs $3 \mathrm{a}$ and $3 \mathrm{c}$ ). In the $\mathrm{ZrO}_{2}-\mathrm{NiO}$ case, the $\mathrm{ZrO}_{2}$ bush roots into the $\mathrm{NiO}$ grain. Moreover, all the $\mathrm{ZrO}_{2}$ bushes grow in one direction (probably [100]) in spite of the curvature 
of the NiO grain surface but they sit on the same planes, probably of the $\{100\}$ family.

These observations indicate the strong interaction between $\mathrm{ZrO}_{2}$ vapor and $\mathrm{NiO}$ substrate though an interaction between $\mathrm{ZrO}_{2}$ and $\mathrm{NiO}$ in the bulk is supposed to be weak. Conventional $\mathrm{x}$-ray study does not show any detectable interaction.

The study of these phenomena in more details is still ahead, but now we might conclude that the observed differences in deposition of $\mathrm{ZrO}_{2}$ vapor on $\mathrm{ZrO}_{2}$ and $\mathrm{NiO}$ substrates are probably the result of differences in their melting temperatures $\left(T_{\text {melt }}\right)$ that differ by almost $750^{\circ} \mathrm{C}$. The EB-PVD process takes place at $0.32 \mathrm{~T}_{\text {melt }}$ for the $\mathrm{ZrO}_{2}-\mathrm{ZrO}_{2}$ system while for the $\mathrm{ZrO}_{2}-\mathrm{NiO}$ system it occurs at $0.42 \mathrm{~T}_{\text {melt. }}$. For the solidification / condensation from the vapor, such differences are critical.

Another reason concerns their different behavior in reducing (vacuum) atmosphere due to

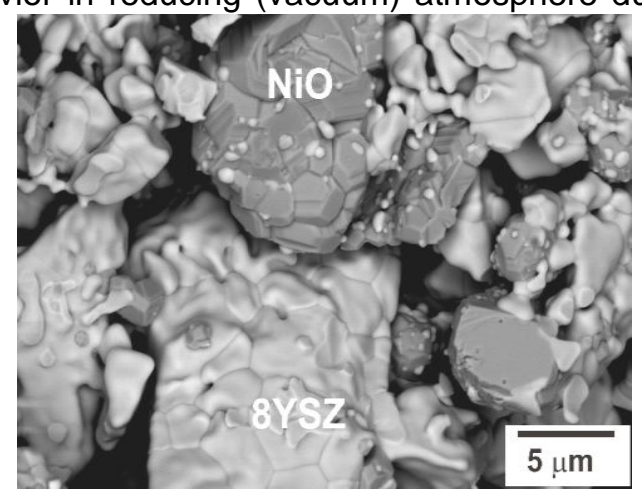

a) their large difference in oxygen affinity that causes different morphological changes, which are seen in the fracture surface of the $\mathrm{NiO}-\mathrm{ZrO}_{2}$ composite (Figs 2 and 5a). Probably zirconia is also promoting reduction of $\mathrm{Ni}$ when it is in contact with $\mathrm{NiO}$ at high vacuum and temperature that results in both faceting of $\mathrm{NiO}$ grains (cubic and hexagonal) and their reduction with formation of a Ni sponge. It can be seen that the surface of $\mathrm{ZrO}_{2}$ grains is smooth with no any sharp edges, which is especially surprising in comparison with the appearance of zirconia grains in pure zirconia ceramics without $\mathrm{NiO}$ (Fig. 5b). NiO grains, in contrast to those of $\mathrm{ZrO}_{2}$, are faceted revealing clearly outlined hexagonal syngony of rather large size (dozen of $\mu \mathrm{m})$. It is obvious that these morphological changes are the result of adsorption of NiO's oxygen by the zirconium. Amorphization of the zirconia grain surface may also be as an additional reason of their "as-fused" appearance.

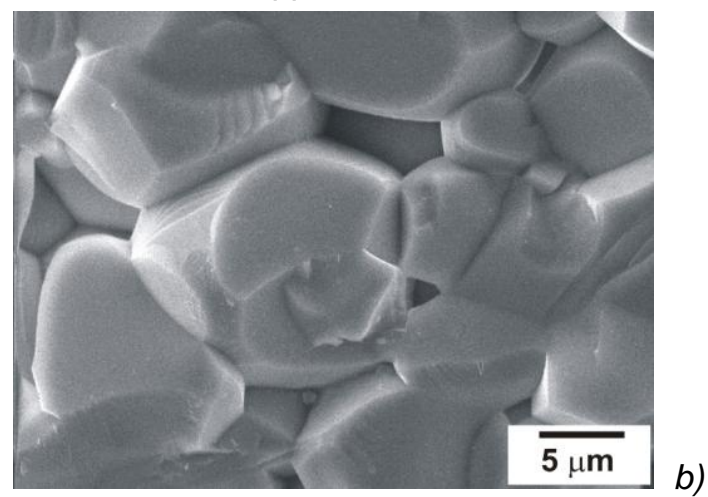

Figure 5 - SEM pictures of fracture of NiO-8YSZ composite (a) and 1Ce10ScSZ ceramics (b) [11]

\section{CONCLUSIONS}

The dense helium impermeable zirconia coatings to be deposited on highly porous substrate with EB-PVD is possible.

The data obtained with transmission and scanning electron microscopy of the transitional zone between an EB-PVD zirconia film and its porous $\mathrm{NiO}-\mathrm{ZrO}_{2}$ substrate (anode - electrolyte interface) allow formulating plausible mechanisms of the $\mathrm{ZrO}_{2}$ condensation from its vapor phase on $\mathrm{ZrO}_{2}$ and $\mathrm{NiO}$ substrates during the EB-PVD process:

In general, the $\mathrm{ZrO}_{2}$ condensation occurs in two stages with two mechanisms of growth - planar and cellular - by analogy with the solidification of the liquid.

The nucleation of $\mathrm{ZrO}_{2}$ coating is phase dependent, and being deposited on $\mathrm{ZrO}_{2}$ and $\mathrm{NiO}$ phases of the $\mathrm{NiO}-\mathrm{ZrO}_{2}$ composite occurs with two different routes, which, summarily, may be determined as the "defective layer by defective layer" for $\mathrm{ZrO}_{2}$ case, and as isolated "islands" for $\mathrm{NiO}$ case.

The structural features related to the $\mathrm{ZrO}_{2}$ root at the $\mathrm{ZrO}_{2}-\mathrm{NiO}$ interface may be responsible also for the high adhesion of zirconia films deposited on porous $\mathrm{NiO}-\mathrm{ZrO}_{2}$ composites with EB-PVD.

High density of the planar growth layers and the existence of the deposition affected zone as well as doping it with $\mathrm{Ni}$ are probably responsible for the increased elasticity modulus of the film areas bordering the anode-electrolyte interface.

The lateral growth of secondary branches / filaments and orientational independence of zirconia-on-zirconia growth are the reasons of good coverage of highly porous $\mathrm{NiO}-\mathrm{ZrO}_{2}$ composites by the dense zirconia film meeting SOFC requirement for He leakage. The orientational dependence of zirconia-on-nickel oxide growth and rooting $\mathrm{ZrO}_{2}$ into $\mathrm{NiO}$ substrate is responsible for a high adhesion of $\mathrm{ZrO}_{2}$ to $\mathrm{NiO}$ phase and all $\mathrm{ZrO}_{2}$ coating on porous $\mathrm{ZrO}_{2}-\mathrm{NiO}$ substrate.

The deposition affected zone surrounding the nucleation site of $\mathrm{ZrO}_{2}$ on the $\mathrm{NiO}$ substrate is clearly discerned. It is a result of the entire phenomenon complex related to interaction of atoms and their clusters with a substrate in analogy with the heat affected zone in welding. 


\section{Acknowledgements}

The authors are grateful to NATO, their "Science for Peace" project N980878 "Solid Oxide Fuel Cells for Energy Security", the European FP6 projects: "Demonstration of SOFC stack technology for operation at $600{ }^{\circ} \mathrm{C}$ (SOFC600)" and students exchange program of "RealSOFC", INTAS project "Structure Optimization of SOFC Based on Scandia Doped Zirconia Ceramics for Space Application" as well as the National Academy of Science of Ukraine, their projects "Structural Fundamentals of Materials for Zirconia Ceramic Fuel Cells" and "SOFC structural optimization based on consideration of interdiffusion at manufacturing and operation", for their respective support.

\section{REFERENCES}

[1] Б.Мовчан, И.Малашенко (1983) Жаростойкие покрытия, осаждаемые в вакууме, Наукова Думка, Киев.

[2] M.Ohring (1992) The Materials Science of Thin Films, Academic Press.

[3] I.Petrov, P.Barna, L.Hultman J.Greene (2003) Microstructural Evolution during Film Growth, J. Vacuum Science \& Technology, 21, 117-128.

[4] Б.Мовчан, А.Демчишин (1969) Исследование структуры и свойств толстых вакуумных конденсатов никеля, титана, вольфрама, окиси алюминия и двуокиси циркония, Физика металлов и металловедение, 28, 83-85.

[5] J.Thornton (1977) High Rate Thick Film Growth, Annual Review of Materials Science, 7, 239-260.

[6] M.Andrzejczuk, O.Vasylyev, M.Brychevskyi, A Smirnova, M.Lewandowska, K. Kurzydłowski, R.Steinberger-Wilckens, J.Mertens, V.Haanappel (2012) Structural Features and Gas Tightness of EB-PVD 1Ce10ScSZ Electrolyte Films, Materials Science-Poland, 30(3), 170-179 (http://www. materialsscience.pwr.wroc.pl/DOI:10.2478/s13536012-0025-0)
[7] O.Vasylyev, Pryshchepa, Vereshchak A.Smirnova, M.Brychevskyi, I. L.Dubykivskyi, A.Samelyuk, V. J.Malzbender (2009) EB-PVD Electrolyte Films: Structure, Mechanical Properties and Conductivity, ECS Transactions, 25, 16871699.

[8] B.Meng, X.He, Y.Sun, M.Li. (2008) Preparation of YSZ electrolyte coatings for SOFC by electron beam physical vapor deposition combined with a sol infiltration treatment. Materials Science and Engineering ,B150, 83-88.

[9] X.He, B.Meng, Y.Sun, B.Liu, M.Li. (2008) Electron beam physical vapor deposition of YSZ electrolyte coatings for SOFCs, Applied Surface Science, 254, 7159-7164.

[10] O.Vasylyev, A.Smirnova, M.Brychevskyi, I. Brodnikovskyi, V.Vereshchak, S.Firstov, G. Akimov, Yu.Komysa, J.Irvine, C.Savaniu, V.Sadykov, I.Kosacki (2011) Structural, Mechanical, and Electrochemical Properties of Ceria Doped Scandia Stabilized Zirconia, Material Science of Nanostructures, 1, 70-80.

[11] O.Vasylyev, M.Brychevskyi, I.Brodnikovskyi, L. Dubykivskyi, S.Firstov, M.Andrzejczuk, M. Spychalski, M.Lewandowska, K.Kurzydlowski, R.Steinberger-Wilckens, J.Mertens, J. Malzbender (2014) Nucleation and growth mechanisms of zirconia film deposited on porous nickel oxide zirconia substrate by electron beam - physical vapor deposition. Advances in Ceramic Science and Engineering, 3, 25-35.

[12] B.Chalmers (1964) Principles of Solidification, New York, Wiley \& Sons.

[13] A.Vasilyev (1980) The Mechanical Properties of Single-Pass Weld Metal in Respect of Its Solidification, Weld Pool Chemistry \& Metallurgy, Welding Institute Reprint, London, UK, proceedings, p.3-8.

[14] D.Matthews, V.Oceli'k, P.Bronsveld, J.De Hosson (2008) An Electron Microscopy Appraisal of Tensile Fracture in Metallic Glasses, Acta Materialia, 56, 1762-1773.

\section{IZVOD}

\section{EB - PVD HELIJUM - CIRKON KERAMIČKI PREMAZ NA POROZNOJ KERAMIČKOJ PODLOZI}

Gusti helijum cirkon nepropusni premaz deponovan je na visoko poroznu NiO-ZrO 2 podlogu na EB-PVD proučavan je putem elektronskog mikroskopa. Utvrđena je kondenzacija cirkonijuma iz parne faze na cirkonijumoksid i nikloksid podlogu. Kondenzacija cirkonijuma je identifikovana kao dvostepeni postupak sa dva mehanizma rasta, ravanski (planarni) i celularni, slično očvršćavanju tečne faze. $\mathrm{ZrO}_{2}$ kondenzuje na podloge $\mathrm{ZrO}_{2}$ i NiO različitim mehanizmima. Tokom ravanskog rasta na sloj $\mathrm{ZrO}_{2}$, stvara se nukleus filma $\mathrm{ZrO}_{2}$ sloj na sloj, debljine oko 0.3-0.5 $\mu \mathrm{m}$. Planarni rast filma $\mathrm{ZrO}_{2}$ na sloj NiO je nepovezan porozan, debljine od 0.5-0.7 $\mu \mathrm{m}$; sastoji se od orjentisanih strukturalno savršenih "ostrva". Uočene razlike pri kondenzaciji su verovatno posledica u razlici temperatura topljenja $\mathrm{ZrO}_{2}$ i NiO i afiniteta $\mathrm{Zr}$ i Ni prema kiseoniku, kao i zbog njihovih različitih ponašanja pod visokim vakuumom. Depozicija utiče na zonu koja je uspostavljena oko nukleusa $\mathrm{ZrO}_{2}$.

Ključne reči: cirkon-keramički premaz; gas helijum-zaptivenost; mehanizam nukleacije; mehanizam rasta; tanki film; elektronski snop-depozicija parom.

\section{Naučni rad}

Rad primljen: 28.01.2016.

Rad prihvacen: 04.03.2016.

Rad je dostupan na sajtu: www.idk.org.rs/casopis 